\title{
The Beauty of Nature and Harmony--On the Ecological Consciousness
}

\section{in Keats's Poetry}

\author{
Yan $\mathrm{Xiao}^{1}$, Ying Yang $^{1}$ \\ ${ }^{1}$ Foreign Language College, Wuhan Bioengineering Institute, Wuhan, Hubei, 430415, China)
}

Keywords: Keats’ poetry, Ecological criticism, Ecological consciousness

\begin{abstract}
Keats had a strong sense of responsibility for nature in his short life. He loved nature with a charitable heart, praised nature and constantly understood the relationship between man and nature and the law of nature development, which formed his view of nature. From the perspective of ecological ethics criticism to interpret Keats' works, we find the beauty-appreciation of Keats' poetry is one kind of supreme ecological ethics appreciation. The political tendency in Keats' Poetry contains his desire for freedom and democracy, artistic pursuit for truth, goodness and beauty, and the wish for harmonious spiritual ecology. Based on the author's reading experience of Keats, this paper analyzes the change of Keats' ecological view and studies the ecological nature of truth, goodness and beauty in Keats' poetry.
\end{abstract}

\section{The Change of Keats' Ecological View}

Keats’ optimistic ecological view. In Keats' early poetry declaration Sleep and Poetry, he took the Flora Kingdom as the beginning place for his poetry journey. First, he went to the Flora Kingdom and Faun Kingdom where he enjoyed nature surrounded by the green world, from tranquil grass to lively animals. He depicted a vivid ecosystem. We feel personally on the scene when reading this poem: little wildflowers bloom fully and quietly on an oasis to enjoy the beauty of life. Birds are flying above the flowers and have companion frolic sometimes. A babyish deer is lying quietly on the grass and enjoying the warm flower bed. What a harmonious ecological landscape picture! However, the poet still described the taste of grass and the terror of thorns which painted gray color to this poem. The author's description of the grass taste stimulates readers' olfaction. On one hand, this reminds people of the dirty mood of society in the time and the sufferings in the real world. On the other hand, the word bitter also allows readers to immediately think of the increasingly destructive environment. But his ecological view and outlook on life are optimistic, which can be proved by the coexistence of myrtle and bitter bushes, the cleared thorns and the birth of deer. The author's desire to restore the ecological balance is strong.

The change of Keats' ecological view from optimism to pessimism. In contrast, Keats ecological view has greatly changed in Endymion. He changed his optimism over the past to describe the environmental deterioration: the original tranquil shade became gloomy and horrible; drifting toxic smog; turbid creek; bleached dead fish; blood-red roses. The poet described a terrible world with a lack of sunlight and green, which reflects a different ecological view from his early poem Sleep and Poetry. This dead lifeless world shows ecological unbalance directly and distinctively in Keats' poetry and it is the author's downright negation to the real life. This may be exaggerated in his poem, but this exaggeration shows poet's despair to the environmental destruction. Sufferings in the real world and the unreachable ideal world make the poet killed by grief. The gap between ideal world and reality cannot be narrowed, which generates conflicts and 
contradiction between poet's spiritual world and the real world. He had been caught in these conflicts and could not help himself. The poet once fancied: like a butterfly helm/ garland and rustic trees/ beautiful music of roses in orchard. He is like a greedy child who hopes to include all beauty of nature into his poetry. However, all these have gone and the next is the imminent destruction of the kingdom: my kingdom is being destroyed/ I die along with it/ nothing inappropriate. As a saying goes that nothing is more lamentable than a dead heart. The devastation of the poetry dream departure place and personal inability against it are enough for the poet to look forward to death. The missing of real world makes the dream a refuge for sufferings. When a poet who is obsessed with aesthetic beauty is unable to record beauty no longer, his despair can be imagined. When dream is disillusioned, what is the significance of life to him?

Keats' vision for the restoration of ecological balance. From the above content, we can see that Keats' ecological view has changed from optimism to pessimism and from the longing for nature to the aversion to ecology. His disagreeable attitude to ecology began to change until August, 1819. In the end of August, he wrote a letter to Fanny: Good weather for two months in a row is a great deal of happiness for me. My nose is no longer frozen red and I do not shiver all day long. Such fresh air is suitable for me to think ... But back to where we were, I still really like the weather here. I see such good weather as the best blessing I could have. The words, good weather and best blessing, all revealed the poet's concern on ecology and his joy of good weather. On September 21, 1819, Keats wrote a letter to his friend Reynolds: Such season is so beautiful --- how fresh the air is! A moderately cold is not a joke. I've been so fond of the beautiful weather and Diana-like sky, which make me so pleased of the residual field. Actually it is really better than the cold green in spring. Somehow the residual field gives warmth as some paintings which give a warm feeling. On Sunday morning, I took a walk and this had a strong impression on me, so I wrote a poem. It is the famous poem-To Autumn. From the beginning of the poem, the poet displays a season of mists and mellow fruitfulness, which is filled with warmth. The poet used painting techniques in a merry and lively manner to satisfy the readers' senses. This pastoral scene is actually a description of nature which has been transformed by human social performance. Ecosystem is heavily influenced by human power. But in the second quarter, the poet used the soothing rhythm to make human out of central position and express his longing for the return to nature by describing the close harmonious relationship between a female image and nature. At the same time, it proved the poet's delight after the ecological restoration. At the end of the poem, the poet wrote the revival in all unions in spring. Spring full of vitality is a start of another ecological cycle. To Autumn creates a harmonious world, which is the change of the poet's pessimistic ecological view and is a symbol of ecological rebalancing world. Compared to Keats' other poems which mapped out ecological views, the poem, To Autumn, carried more hope.

\section{The Ecological Nature of Truth, Goodness and Beauty in Keats' Poetry}

The Art in Keats' poetry contains rich implications of truth, goodness and beauty. The sentence that beauty is truth, truth beauty in Ode on an Grecian Urn, is a summary of the nature of poetry and it is his famous aesthetic ideology. The aesthetic ideology is a reward for his love of nature, his life's work and poetry fruit which Keats exchanged for with his life. In his letter to Fanny Blau, he wrote: If I died, I said to myself, and left no immortal work and nothing can make my friends proud of me, but I have always loved the essence of beauty in everything. If I have enough time in the past, I will let future generations remember me. When I'm healthy and every pulse beats for you all the time, this kind of thinking is very weak. Now you can share all my thoughts with this (I can say that?) last sick man who is a lofty wise man. This is the light of life that a gifted poet brought forth in his short 
life.

Keats thought the real thing refers to the sun, the moon and stars and Shakespeare's drama. Semi-real things, such as love, clouds, need spiritual care to get the full presence; nothingness needs a hot pursuit to endow greatness and dignity. In order to show the aesthetic ideology, Keats usually integrated beautiful legend or magic nature with views of real life: such the sun, the moon/ trees old and young, sprouting a shady boon / for simple sheep and such are daffodils/ with the green world they live in and clear rills / that for themselves a cooling covert make/ gainst the hot season the mid forest brake/ rich with a sprinkling of fair musk-rose blooms/ and such too is the grandeur of the dooms/ we have imagined for the mighty dead/ all lovely tales that we have heard or read/ an endless fountain of immortal drink/ pouring unto us from the heaven's brink. (Endymion) The truth and beauty include the past, present and future in time and include nature and human society in space. He made use of emotional sympathy to integrate them harmoniously, so that it has a spiritual effect on the human exploration deeply.

The realization of truth and beauty in Keats poetry is related with goodness which is the fundamental understanding of social ethics. Throughout Keats' poetry, ecological fracture and ecological harmony are the main content. At the same time, the pursuit of freedom and anti-tyranny are his spirit. In On Peace he wrote: o Europe/ let not sceptred tyrants see/ that thou must shelter in thy former state/ keep thy chains burst/ and boldly say thou art free. In 1815, in The Day of the Release of Lee - Hunter, Keats wrote: so what, in order to curry favor with the regime/ clarify the truth, kindly Hunter was behind bars/ but like a lark searching the sky/ freely soar circling in his immortal spirit. If the former is a complaint and criticism to the strength of the European powers at that time, the latter is to praise the spirit of freedom and democracy. It is clear that Keats' goodness is to concern about nature, life and social ethics. It is not only the basis for the establishment of truth and beauty, but also the best state of truth and beauty. In other words, it is only on the basis of goodness which fully demonstrates the humanistic care spirit, beauty in Keats' poetry can have a figurative presence.

At the same time, we should also see that Keats, like other Romantic poets, used the power of imagination to combine art and life together in the pursuit of truth, goodness and beauty, which makes Keats' poetry art and his consideration and reflection on real life closely linked. He also indicated inwardly the inspiration of lifestyle and its development trend. His revelation to goodness is not limited to ethical preaching, but to reveal interwoven complexity in humanity by describing characters' behavior in his poetry. He disclosed the conflict between good and evil and the antinomy between them. The awareness of goodness is based on the tragic consequences that the evil brought about to the good. On the superficial layer, objects in Keats' description in poetry are myths and legends, ancient stories and praise of nature, but it deeply presents the true feature of the human soul in a roundabout way. Then he went deep into the social care from this perspective, so he transformed ego's love to borderless love and it will greatly enhance the meaning and significance of Keats’ poetry.

\section{Conclusion}

Keats' poetry runs through active natural aesthetic characteristics and political awareness. The coexistence of both is not only contradictory and mutually exclusive, but also interactive and interpenetrative, which contains the poet's experience on personal life and social reality, his desire for freedom and democracy, and his pursuit of beauty in poetry. This is actually an expression of the poet's aesthetic consciousness and his desire for spiritual ecological harmony. It displays his broad humanistic spirit, which hide in the aesthetic expressions in his poetry. Therefore, it should be said 
that Keats' wish for nature, longing for the sublime beauty-appreciation and his pursuit of freedom and democracy achieve a harmony in spirit and the subconscious, which forms nature-respecting humanist spirit.

\section{Acknowledgements}

Fund Project: 2015 annual humanities and social science research projects of Hubei Province Department of Education: the Construction of Ecological Ethics in English Romantic Poetry (15G131).

\section{References}

[1] Li Xiaojun. Aesthetics History Ecology--- A Study on Paradigm Transformation in Keats'Poetry from the View of To Autumn [J]. Foreign Language and Literature, 2004, 03: 54-59.

[2] Guo Feng. A Study on the Ecological Thought in Keats’ Poetry [J]. Journal of Zhejiang Normal University (Social Sciences), 2010, 05: 88-92.

[3] Yang Shangen, Su Jing. A Viewer of Natural Beauty and Truth--- the Ecological Consciousness in Keats’ Poetry [J]. Journal of Qinzhou University, 2010, 05: 63-66.

[4] Liu Fuli. A Study on Ecological Ethics Poetic Construction in Keats in Ode on a Grecian Urn [J]. Hubei Social Science, 2011, 01: 144-147.

[5] Luo Meiling. Beauty in Harmony---A Study on Keats' Ecological Wisdom Based on Corpus [J]. Journal of Yichun University, 2011, 10: 117-119 + 141. 